\title{
METHODOLOGICAL REFLECTION ON THE HETEROCHRONIA IN THE CONTEXT OF DEVELOPMENT OF A HEALTH PRESERVING COMPETENCE OF A PHYSICAL EDUCATION TEACHER
}

\author{
Mykola Yevtuch \\ Institute of Pedagogics, National Academy of Educational Sciences of Ukraine, Ukraine \\ Vasyl Fedorets \\ Communal Higher Education Institute "Vinnytsia Academy of Continuous Education”, \\ Ukraine
}

Oksana Klochko

Vinnytsia Mykhailo Kotsiubynskyi State Pedagogical University, Ukraine

\begin{abstract}
The article presents the methodology of using knowledge about the phenomenon of heterochronia in pedagogy. The aim of the study is to improve the methodology of development of health-saving competence of Physical Education teacher in postgraduate education based on actualization and understanding of the phenomenon of heterochronia. The use of knowledge about the phenomenon of heterochronia is considered in the context of pedagogical anthropology and conducted within the framework of phenomenological, health-saving and anthropological approaches. Approaches used in the research are the following: competence, axiological, existential, transdisciplinary, etc. Due to the use of the phenomenon of heterochronia, the temporal phenomenology of a person is represented, as well as its nonlinearity, processability. Knowledge of the phenomenon of heterochronia and its value interpretations is used in the pedagogical methodology of prevention of sudden cardiac death. The use of knowledge of heterochronia promotes the effective application of Physical Education teacher the knowledge of human morphophysiology in educational practices of health preservation and axiologicalization and humanization of the educational process. The results of the conducted study determine quite considerable prevalence of knowledge as well as value and health oriented understandings of heterochronia among the working Physical Education teachers in comparison with students mastering this profession.

Keywords: axiology, coach, early learning, health preserving competence, heterochronia, methodology, Pedagogy of health, Physical Education teacher, post-graduate education, prevention, sudden cardiac death.
\end{abstract}


Yevtuch et al., 2020. Methodological Reflection on the Heterochronia in the Context of Development of a Health Preserving Competence of a Physical Education Teacher

\section{Introduction}

The peculiarity of the cognitive (intellectual-value) component of the health preserving competence of a Physical Education teacher (Mamakina, 2013; Fedorets, 2017) lies in the fact that professional visions, thinking, cognitive schemes are aimed at preserving life and health thus determining the need to develop value based and fundamental knowledge about the nature of a person (Ancient Greek $\varphi v ́ \sigma ı \varsigma ~ \tau o v ~ \alpha ́ v \theta \rho \omega \pi o v)$ (Jeger, 1997, p.15, p. 27, p. 33-35). The crucial role in the effective formation of the stated cognitive component is played by the awareness about, understanding and interpretations of the anthropological phenomena, which are systemic, comprehensive, structuring, system-organizing, border, temporal as well as alerting about possible threats to life (Fedorets, 2011) and health. One of such central and significant phenomena is heterochronia (Ananev, 1980, p. 65-123; Anohin, 1968, p. 80-82), which reflects the temporal nature of a person and everything living in a comprehensive and representative way.

In the context of using anthropological phenomena that have practical significance to develop the health preserving competence of a Physical Education teacher, we focus on the educational problematics of sudden cardiac death (Berger et al., 2004; Van Camp et al., 1995; Fedorets, 2011; Higgins \& Andino, 2013; Maron \& Estes, 2010; Steinvil et al., 2011; Shvalev, Sosunov, \& Guski, 1992). Anthropological-value and practically oriented comprehension of the disease's phenomenology includes the study of the methodological-value problematics of the non-lineal and uneven development of a child, i.e. of heterochronia, which is a biological precondition of development of the stated pathology.

Scientific pedagogical literature does not sufficiently highlight the singledout, specified (concrete) and targeted use of the heterochronia phenomenon for the improvement of the methodology of development of the health preserving competence of a Physical Education teacher in conditions of the post-graduate education. The combination of the educational significance of the professional and competence aspects of the problem of methodological reflection on the heterochronia phenomenon and its importance for preserving children's life and health in conditions of the educational process, which have been stated above, makes our study relevant and necessary.

The aim of our research is to improve the methodology of development of the health preserving competence of a Physical Education teacher in conditions of post-graduate education on the basis of methodological-value reflection and health oriented representation of the heterochronia phenomenon as well as through temporal-ontological and onto-genetic perception of the educational problematics of sudden cardiac death prevention. 


\section{Theoretical Basis of the Research}

Phenomenon of heterochronia was primarily defined as a biological one, and the term itself was introduced in the $19^{\text {th }}$ century. A "bright" example of heterochronia is the quickened development - acceleration. Studies of P. Anohin (1968, p. 76-109), B. Ananev (1980, p. 65-123) and others make up the foundation of heterochronia understanding that was formed within the framework of physiology, psychophysiology and psychology. Primarily, quality changes of the ontogenetic and temporal nature of a person are reflected in the unevenness of development, growth, formation as well as in the processes of involution (ageing) (Ananev, 1980, p. 66).

P. Anohin's Theory of Functional Systems (Anohin, 1968, p. 76-109, p. 194262; Anohin, 1998; Krivo, 2018) is a contemporary experimentally proven theory, within the framework of which the ideas of heterochronia are being actively used. It claims that knowledge, skills, abilities, traits of character, behavioral stereotypes and the personality itself are all functional systems. Competences are also viewed as functional systems. According to the System Genesis Theory of P. Anohin (Anohin, 1968, p. 80-82), heterochronia are the defining, central and system organizing conditions of functional system formation; and this should be taken into consideration both while organizing the educational process and while actually conducting a lesson.

The relevant dimension of heterochronia problematics is phenomenology of health and its preservation. Using the study of P. Anohin (Anohin, 1968, p. 76109, p. 194-262; Anohin, 1998; Krivo, 2018), we view health as a functional system, which is being formed and exists heterochronically. The fact that a personality also forms and exists heterochronically (Ananev, 1980, p. 65-123) indicates the "comprehensiveness" of heterochronia and their systemic character. As B. Ananev puts it, “...the start of the personality happens much later than the start of a person” (Ananev, 1980, p. 67).

Studies that reveal the phenomenology of heterochronia lie primarily in the fields of biology, physiology, psychophysiology, defectology, medicine and psychology. In pedagogics the stated topic has not been thoroughly studies yet. That is why the domineering understandings of a person (a child) and the processes of his/her development, including the formation of knowledge, skills, abilities, competences are often being developed on the basis of "simplified", lineal and deterministic ideas in which the non-lineal, uneven and temporal human nature is not fully taken into consideration 
Yevtuch et al., 2020. Methodological Reflection on the Heterochronia in the Context of Development of a Health Preserving Competence of a Physical Education Teacher

\section{Methods of the Research}

In this research, we use the theoretical analysis of the scientific sources as well as a system of approaches, which includes competence (Raven, Yarygin, \& Korostelev, 2017), health preserving (Fedorets, 2011, 2017; Fedorets \& Klochko, 2019), axiological, hermeneutical, phenomenological (Gusserl, 2004), ontological, reflexive, existential (Binswanger, 1942), systemic (Bertalanffy, 2009), target, anthropological (Bertalanffy, 2009; Bollnow, 1971; Ushinskij, 2005), holistic, problematic, transdisciplinary approaches.

We applied methodologies of such scientific fields as existential philosophy; bio-semiotics (Millikan, 1984; Knyazeva, 2018), phenomenological philosophy (Gusserl, 2004); pedagogical anthropology (Bollnow, 1971; Ushinskij, 2005) and philosophical anthropology. We used the concepts of knowledge transfer (Nonaka \& Takeuchi, 2011); personal knowledge (Polani, 1985); functional systems (Anohin, 1968, 1998; Krivo, 2018); anthropologization (Bollnow, 1971; Ushinskij, 2004). On the basis of epistemological operations of extrapolation, analysis, problematization and using the hermeneutical approach to define the educational phenomenology of risks of sudden cardiac death development, we provided value and health preservation based interpretations of the results of morphological, neuro-physiological, neuro-morphological (Shvalev et al., 1992) and clinical cardiac studies.

We have actualized the methodological-worldview and methodological-

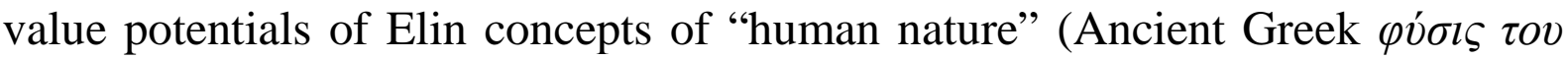

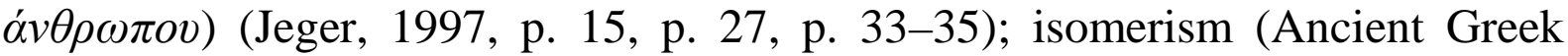
$\tau \imath \mu \omega \rho i \alpha)$ - harmonious, balanced and proportional correlations between the components of a person and between a human being and the surrounding world

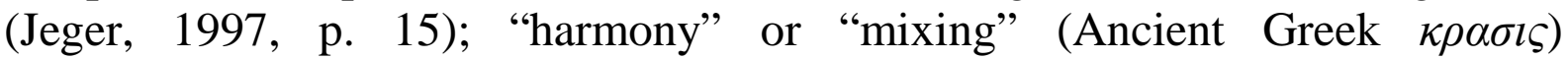

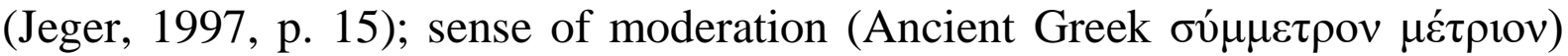

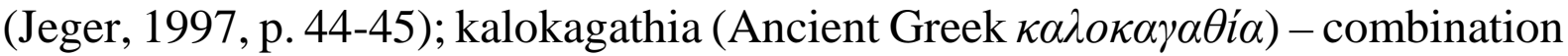
of beauty and harmony with goodness as well as the merging (integration) fieldof corporal and spiritual (Jeger, 1997, p. 45); the care of the self (epimelēsthai sautou) described by M. Fuko (Fuko, 2008).

For this particular research, we have developed and used a Fedorets-Klochko questionnaire entitled "Determining heterochronically oriented interpretation of health preservation" that we present below:

1. At the body level, ontogenetic and morpho-physiological sudden cardiac death risk factors in children while doing physical exercise are: 1) uneven body development; 2) insufficient training level of a child; 3 ) lack of vitamins (correct answer - 1).

2. At the cardiac level ontogenetic and morpho-physiological sudden cardiac death risk factors in children while doing physical exercise are: 
1) lack of heart nutrition; 2) uneven development of the heart; 3) insufficient training level of the heart (correct answer - 2)

3. Rapid growth of a child, which is accompanied by body mass growth indicates the necessity: 1) not to introduce changes in the training routine; 2) to increase the exercise load while doing sports and exercising; 3) to decrease the exercise load while doing sports and exercising (correct answer - 3).

4. Even growth and development of a child are indicators of: 1) health; 2) such phenomenon is impossible; 3) harmonious development (correct answer - 2).

5. Uneven growth and development of a child are indicators of: 1) giftedness or normative development; 2) a slight individual development disorder; 3) a significant individual development disorder (correct answer - 1).

6. Uneven growth and development of a child are indicators of: 1) health; 2) health disorders; 3) improper physical activity load and nutrition (correct answer - 1);

7. Normative for a teenager is that cardiac development: 1 ) is faster than body growth; 2) is correlated with body development; 3 ) is slower that body growth (correct answer - 3);

8. Normally, the formation of the emotional sphere of a child: 1) is faster than cognitive development; 2) is slower than cognitive development; 3 ) is synchronized with cognitive development (correct answer -1)

9. Uneven growth, maturing and formation of a child's body is: 1) a pathology; 2) normative; 3) a slight disorder (correct answer - 2)

10. If a child develops unevenly, you should: 1) visit a doctor and a psychologist; 2) consider it to be a peculiarity of a child's development; 3 ) to correct it with sport and healthy nutrition (correct answer - 2);

11. Presence of slight and typical problems with cardiac health in teenagers, which pass with age, is caused by: 1) insufficient training level; 2) peculiarities of individual development, which is uneven; 3) insufficient overall body hardening (correct answer -2 ).

12. Presence in teenagers of relatively compensated behavioral and character problems, which do not lead to stable social maladjustment and which pass with age, is caused by: 1) bad upbringing; 2) unevenness of ontogenesis; 3) hereditary factors (correct answer - 2).

13. Hypersexual behavior of teenagers, which is compensated and does not lead to social maladjustment, is primarily caused by: 1) bad upbringing; 2) typical peculiarities of individual development; 3 ) enhanced nutrition (correct answer - 2). 
Yevtuch et al., 2020. Methodological Reflection on the Heterochronia in the Context of Development of a Health Preserving Competence of a Physical Education Teacher

14. Aggressive behavior of teenagers, which does not lead to social maladjustment, is primarily caused by: 1) bad upbringing; 2) peculiarities of individual development; 3) lack of vitamins in the food (correct answer - 2).

\section{Research results}

Let us look at the phenomenon of heterochronia within the methodologicalvalue and content-sensual frames of an image of a person, temporality and values, sudden cardiac death prevention (Berger et al., 2004; Van Camp et al., 1995; Fedorets, 2011; Higgins \& Andino, 2013; Maron \& Estes, 2010; Steinvil et al., 2011; Shvalev et al., 1992) and methodical work.

An image of a person and Homo Heterochronicum. From the methodological-worldview positions, an image of a person is a primary and system organizing factor both of the health preserving activity of a teacher and of the overall organization of the educational process. Everyone is familiar with images-concepts of Homo Sapiens (a clever person), Homo Educandus (a studying person), Homo Ethicus (an ethical person) and others, which contain the emotionally defined and representatively reflected essential features of a person. An image of a person is among the primary ones in religious and cultural traditions.

The concept of an image of a person and the inseparable deep, spiritual, existential and anthropological values and senses may be considered to be the source of humane and its attributive phenomena. Human ontology (being), axiology, vitality, humanism, mercy, love, wholeness, intentionality, temporality, idea of health and essence of a human being are all "concentrated", reflected and manifested in the image of a person. The issue of an image of a person in its anthropological and humanistic interpretation becomes especially significant nowadays, when an image of a person as a spiritual being capable of transcendence and value-sensible existence is reduced to a simplified "image of a person as a robot" as the author of the "general systems theory" (allgemeine Systemlehre) L. Bertalanffy (Bertalanffy, 2009, p. 191) points out.

Using K. Levin's (Levin, 2000) concept of psychological field in our methodological reflections, we may say that by its very existence, the image of a person a priori conveys, defines and forms high humanistic, humane and merciful values and senses. By perceiving and actualizing the value-sensible and ontological dimensions of an image of a person in conditions of an educational process, we may determine and unveil in a Physical Educational teacher such features as humanism, tolerance, kindness, mercy, love, compassion. So speak of the necessity to actualize the system of co-dependent and inter-related qualities, that an educator needs in order to effectively preserve health and life of children 
the stated qualities are at the same time attributive to the person and are directly linked to the image of a person. Special value of the image of a person lies in the fact that it forms complex perception and understanding of a person by the person him/herself and by the participants of the educational process.

Taking into consideration of the above presented ontological, moral-ethical, value, temporal andactivity understandings of the image of a person, we supplement it with the practically oriented concept of Homo Heterochronicum. Methodological sense of the stated concept is to show the teacher the temporal nature of a person and the unevenness of ontogenesis represented as heterochronia. Consequently, heterochronia is presented as a significant peculiarity of human existence as well as a specific value, a relevant and potential sense, a mode of existence, a way of adaptation and representation, a morphophysiological and systemic precondition of learning and a manifestation of life and creative life. With the help of this concept the non-lineal, multi-dimensional, polyontological, auto-poetic (meaning the ability to self-form, self-develop, selfimprove) nature of a person (Maturana \& Varela, 2000) are represented.

Let us consider the phenomenology of heterochronia using the methodological and axiological potential of Hellenistic concepts. Correspondingly, "human

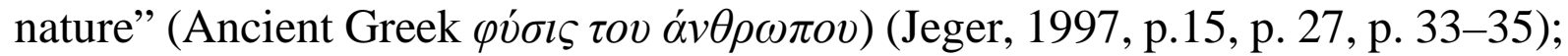
isomerism (Ancient Greek $\tau \imath \mu \omega \rho i \alpha$ ) (Jeger, 1997, p. 15); kalokagathia (Ancient Greek $\kappa \alpha \lambda о \kappa \alpha \gamma \alpha \theta i \alpha$ ) (Jeger, 1997, p. 45) are manifested through Homo Heterochronicum. Despite the fact that heterochronia is an unevenness, it first and foremost is a way of a person's harmonization in ontogenesis and explains the peculiarity of "unveiling" his/her temporality.

Temporality and heterochronic values. On the basis of bio-semantic (Millikan, 1984; Knyazeva, 2018), ontological, existential, temporal and axiological perceptions of the phenomenon of heterochronia, we form a methodological concept of heterochronic values. We define the stated values as such in which non-equilibrium, uneven, processual, temporal, existential, complex, non-lineal, auto-poetic and poly-ontological nature of a person is disclosed in the form of heterochronia, the value interpretation of which is aimed at preservation of health, life and at facilitation of creative life.

From the existential positions (Binswanger, 1942), heterochronic values are an interpretation of existential senses and existentials of space, time and care, as well as their representation in the "visual" life as well as "corporal" and psychological format. Thus, the existence "speaks" in the "visual" format through heterochronia. For example, a person sees and understands that he/she grows or gets older, and this has a deep existential sense.

The heterochronic values integratively present and interpret vitally and with the orientation towards creative life the phenomenology of the image of a person as Homo Heterochronicum, as life and as "human nature"(Ancient Greek $\varphi v ́ \sigma ı \varsigma$ 
Yevtuch et al., 2020. Methodological Reflection on the Heterochronia in the Context of Development of a Health Preserving Competence of a Physical Education Teacher

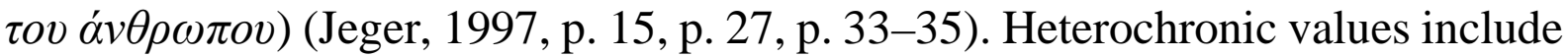
phenomena of various nature: structure and functions of the body, psychological peculiarities,certain period of life etc.

The immaturity of the cardiac nervous system in children under the age of seven (Shvalev et al., 1992), which determines both the age peculiarities of motor activity of children and the possible risks and threats for their life and health, may serve as an example of heterochronic values. Another example is when we speak about adolescence, we voice the heterochronic value and specifics with dominating temporal and vital connotations. The sense of development of the concept of heterochronic values lies in the need to form a delicate, tolerant, merciful, kind, sensible attitude of a teacher towards children, which would be based on the value interpretation of their age, ontological, onto-genetic and temporal peculiarities.

Human temporality, procedurality and existentiality are represented in heterochronic values. Actualization of the temporal nature of a person, unveiled through the value reflection on heterochronia is important as values very often concern special and substantial aspects. This is caused by the fact that domineering understandings and concepts in the European culture are related to spatial phenomena, which can be "easily" represented and formalized. At the same time, temporal phenomena that are reflected in heterochronia have not been sufficiently actualized neither in the professional culture of an educator, nor in the educational theory or in health preserving practices. The development of the concept of heterochronic values is aimed at increasing the efficiency of life and health preservation based on the anthropological-value and existential perception of an image of a person, the human nature and disclosure of a person's temporality, uneven ontogenesis and temporal ontology.

Sudden cardiac death prevention based on the awareness of the heterochronia phenomenon. Sudden cardiac death, a pathology, the risks of which considerably increase while doing sports and physical exercises. That is why, in his/her professional activity, a Physical Education teacher and a coach has to deal with the issue of primary importance, i.e. with sudden cardiac death prevention (Fedorets, 2011) as well as with prevention of other acute and life and health endangering pathologies that include child injury (DiFiori et al., 2014; Gottschalk \& Andrish, 2011), concussion (Powell, 2001) and other disorders.

In order to effectively preserve health, a teacher should see and understand a child, perceiving him/her as a reality, as existence, as temporality, as heterochronia, as a phenomenon. In this context, it is important to "return" to things, to the living world (Germ. Lebenswelt), to existence described by E. Husserl, the founder of phenomenological philosophy (Gusserl, 2014, p. 193200). By interpreting Husserl's ideas, we transform them into methodological stratagems - "Return to the Person", "Return to the Child", to its nature, to its 
temporality, to its ontogenesis (individual development), to its heterochronia. The sense of this approach is the need to form a value-based understanding of the uniqueness of every child's existencein the teacher, taking into consideration the comprehension of anthropological phenomena, in this case of heterochronia.

The idea of this paper is sudden cardiac death prevention in children at Physical Education lessons and while doing sports, using the methodologicalvalue reflections and technological and health oriented perception of the phenomenon of heterochronia. A lot of works study sudden cardiac death (Berger et al., 2004; Higgins \& Andino, 2013; Maron \& Estes, 2010; Van Camp et al., 1995; Steinvil et al., 2011). Academician V. Shvaliov and his scientific school (Shvalev et al., 1992) as well as others have significantly contributed to the understanding of the mechanisms and causes of sudden cardiac death. A Sudden Cardiac Arrest Association [SCAA] operates in the USA and its work is directly aimed at sudden cardiac death study and prevention.

V. Shvaliov (Shvalev et al., 1992) studied that one of the leading morphofunctional reasons of sudden cardiac death is the disorder in the nervous mechanism of cardiac work regulation. The stated regulation mechanismis structurally presented by the cardiac nervous apparatus, which provides a "sophisticated", differentiated adaptation of the heart to various loads. Thus, accordingly to the load the heart forms its optimal working modes that ensure proper blood circulation in the body.

A significant fundamental and at the same time practically oriented idea formed in the course of V. Shvaliov (Shvalev et al., 1992) and his scientific school's studies is that the presence of structural or/and functional disorders in the cardiac nervous apparatus or its involution or immaturity create systemic risks, which facilitate sudden cardiac death occurrence. That is why, for a professionally organized, conscious and targeted sudden cardiac death prevention it is very important to have the system organizing awareness about the fact that cardiac nervous apparatus is formed and destroyed correspondingly to age changes, i.e. heterochronically.

Following the methodological visions, taking into consideration clinical phenomenology of sudden cardiac death and analyzing the works of V. Shvaliov and his scientific school (Shvalev et al., 1992), we may define such main stages of cardiac nervous apparatus maturing and involution as: $1^{\text {st }}$ (since birth until 8 months) - a significant structural and functional immaturity that makes this period the riskiest in terms of pathology development that caused the need to define a specific nosology - the sudden infant death syndrome (Lat. mors subita infantum); $2^{\text {nd }}$ stage (7 years old) - partial structural maturity accompanied by the formation of main structures of the nervous apparatus; $3^{\text {rd }}$ stage (11-13 years)-incomplete structural and functional maturity at the age of $11-13$ years; $4^{\text {th }}$ stage $(18-22$ years) - complete structural and functional maturity; $5^{\text {th }}$ stage (after 33 ) - slow 
Yevtuch et al., 2020. Methodological Reflection on the Heterochronia in the Context of Development of a Health Preserving Competence of a Physical Education Teacher

and insignificant involution; $6^{\text {th }}$ (after the age of 40-42) - involution and agerelated destruction of the nervous apparatus.

Extrapolating the above presented morpho-physiological phenomena, which are determined by ontogenesis, on the educational problematics of preserving children's life and health, we may point out that immaturity of the cardiac nervous apparatus is a risk factor in sudden cardiac death development. Certain factors, among which physical load is a crucial one, especially if it does not correspond with functional abilities of a child and his/her age peculiarities, in combination with the structural-functional immaturity of the cardiac nervous apparatus, may considerably increase the risk of sudden cardiac death.

The conclusion from the above presented age-related cardiac morphophysiology and the issue of sudden cardiac death that would be of practical and methodological value for a Physical Education teacher and a sports coach lies in the need to use the value oriented awareness about the "heterochronia of the heart", which are presented in the form of stages of cardiac nervous apparatus maturity at the age of 8 months and 7, 12, 18, 22 years. To preserve their own health while performing professional functions, coaches should also take into consideration such age milestones as the age of 33 and 40 years. The key morphophysiological peculiarity is the heterochronia of the cardiac nervous apparatus at the age of 22, which manifests itself in different speed of the growth of nervous structures and the myocardium (cardiac muscle) formation.

From the point of cardiac health preservation in pupils during physical load, awareness about another "cardiac heterochronia", which occurs in adolescence and lies in the slower myocardium (cardiac muscle) growth in comparison with the speed of muscular-skeletal development, would be important for a Physical Education teacher and coach. These two stated cardiac heterochronia are also presented in our methodological system as heterochronic values that make the stated awareness about the non-lineal nature of heart and its nervous apparatus development a value, phenomenologically, temporally, existentially and health oriented one.

Applying the stated understanding of heterochronia and actualization of heterochronic values and the Homo Heterochronicum concept facilitates the affective practical and personalized orientation as well as specification (concretization) of perception and interpretation of the uneven and non-lineal body development. Accordingly, they transform into personal knowledge (Polani, 1985) and are included into the structure of the cognitive component of the health preserving competence of a Physical Education teacher.

The development of value oriented understandings of the heterochronic peculiarity of a person in a Physical Education teacher. The ideas and strategies of anthropologization, professionalization, axiologization, phenomenologization, which include the awareness about and the interpretation of heterochronia, 
actualization of heterochronic values and the heterochronic image of a person (Homo Heterochronicum), form the basis of improving the health preserving competence of a Physical Education teacher in conditions of post-graduate education. According to the competence paradigm ideology (Raven, Yarygin, \& Korostelev, 2017) and the health preserving intentions and mindset, we draw attention to the fact that value-based attitudes, orientations and strategies of a teacher, aimed at harmonization of a child's existence taking into consideration heterochronia, are significant for health preservation.

We unveil the stated strategies using the Elin concepts. Thus, we single out heterochronia harmonization strategies, which include: the care of self (epimelēsthai sautou) (Fuko, 2008), which is also interpreted as existential care about the pupils and harmonization of their heterochronia; the sense of moderation

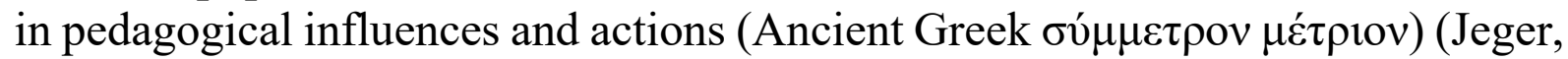
1997, p. 44-45); facilitating correlation or isomerism (Ancient Greek $\tau i \mu \omega \rho i \alpha$ ), which is aimed at forming harmonization, correlation and congruence between a person (a child) and the environment and situations as well as self-harmonization of a child.

In 2017-2019 we conducted a research in order to comprehend the practical significance of the issue of heterochronia in improving the health preserving competence of a Physical Education teacher. The research was conducted in: the Drohobych Ivan Franko State Pedagogical University - 15 people (future specialists in Physical Culture and Sport), 26 people (teachers of Physical Education who were taking their qualification upgrading courses); Vinnytsia Mykhailo Kotsiubynskyi State Pedagogical University - 7 people (future specialists in Physical Culture and Sport); Vinnytsia Humanitarian Pedagogical College - 48 people (future specialists in Physical Culture and Sport); T.H. Shevchenko National University “Chernihiv Collegium” - 11 people (future specialists in Physical Culture and Sport); K.D. Ushynskyi Chernihiv Oblast Institute of Post-Graduate Pedagogical Education - 24 people (teachers of Physical Education who were taking their qualification upgrading courses); Mykolayiv Oblast Institute of Post-Graduate Pedagogical Education - 18 people (teachers of Physical Education who were taking their qualification upgrading courses). The Questionnaire entitled "Determining heterochronically oriented interpretation of health preservation" (presented above in "Methods of the Research") was used in the research. In the course of the research we compared the value oriented awareness of the heterochronia phenomenon among the teachers of Physical Education who were taking their qualification upgrading courses (68 people) and the future specialists in Physical Culture and Sport (81 people). $53 \%$ of the teachers who were taking their qualification upgrading courses demonstrated high level of knowledge, 36\% - medium and 11\% - low. As for the future specialists in Physical Culture and Sport, 18\% demonstrated high 
Yevtuch et al., 2020. Methodological Reflection on the Heterochronia in the Context of Development of a Health Preserving Competence of a Physical Education Teacher

level of knowledge, 41\% - medium and 41\% - low (Fig.1). Thus, if compared with future specialists in Physical Culture and Sport, teachers of Physical Education who were taking their qualification upgrading courses demonstrated a considerably higher level of value oriented knowledge about the heterochronia phenomenon.

Heterochronia is a biological and existential phenomenon that reflects the uneven, nonequilibrium, nonlinear, stage growth and formation of a person and the temporal specificity of the development of his knowledge, skills, competences, functional and adaptive capacities.

The updating of knowledge and interpretations of the phenomenon of heterochrony to improve the health-saving competence of Physical Education teacher is carried out in accordance with established traditions of pedagogical anthropology, ideas of humanization of the educational process, as well as within the phenomenological, natural, ontological, problematic, age-related and healthbased approaches.

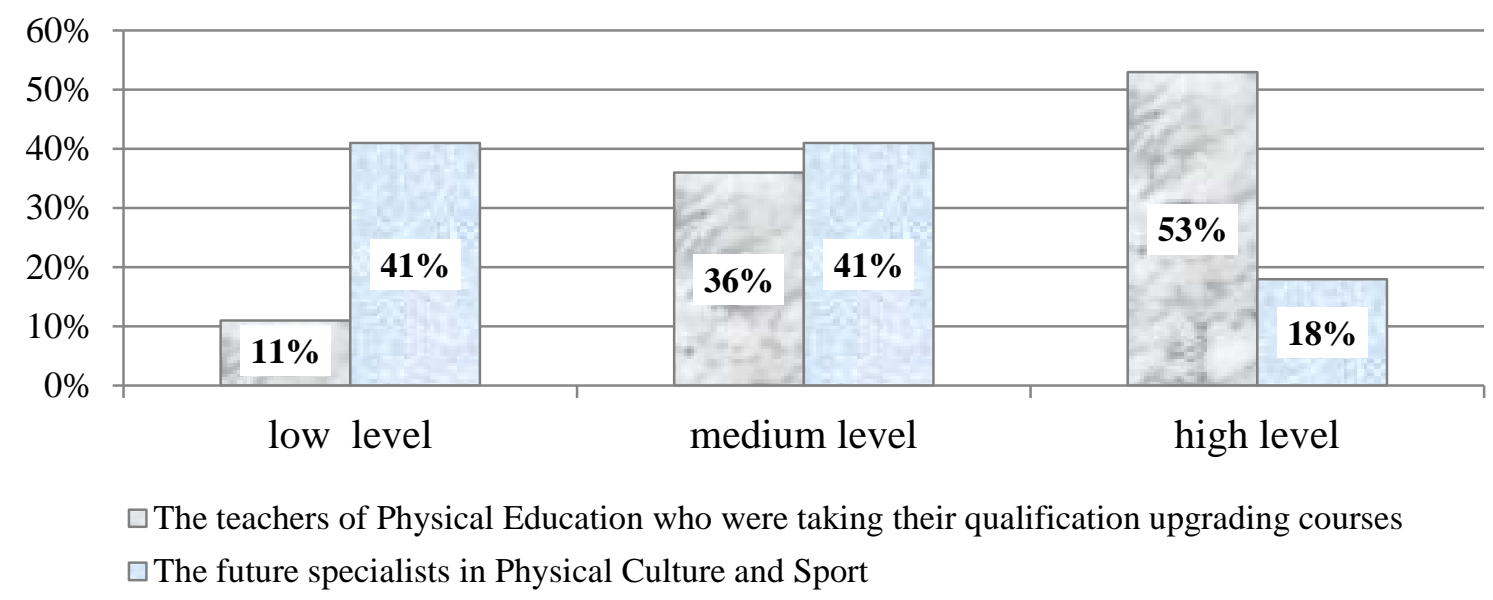

Figure 1 The value oriented awareness of the heterochronia phenomenon among the teachers of Physical Education who were taking their qualification upgrading courses and the future specialists in Physical Culture and Sport

The need for the use and significance and value of application in the pedagogical theory and practice of knowledge of heterochrony is determined by many aspects, they: promote the development in a Physical Education teacher of a modern science-based, objectified, humanistic, phenomenological, and existential conception of the human being as a polyontological and multidimensional being, which has its own special path of development and existence; change the reduction, mechanistic conceptions of the person into the personality oriented, phenomenological, temporal and existential; open ways of effective application of differentiated, health-saving, innovative, creative and 
personality-oriented approaches at a new qualitative level, because they give an opportunity to visually see and understand the deep anthropo biological mechanisms of development and development of both human and individual functions, knowledge, competences; present to the teacher a procedural, dynamic and temporal vision of the person as opposed to the traditional "object", that is, they give an understanding of "man as time", "man as process"; visually reveal the stages of human development and determine a practically oriented understanding of sensitive and crisis age periods, deepening the special knowledge about them; form a teacher's understanding of their limits of influence on the child and contribute to the formation of a tolerant and caring attitude towards the person; is an epistemological condition not formal but meaningful and phenomenologically oriented health care, education and upbringing.

In support for this, we give examples of heterochrony relevant to the educational process: crisis and sensitive periods; memory is a leading mental function in children under the age of six, which some understand as developed intelligence and giftedness; lack of attention in 5-6 year old children makes it futile to try to train it at that age; immaturity of the musculoskeletal system in 56 years with prolonged sitting in the conditions of early learning is a prerequisite for the development of scoliosis and slouch; the formation of knowledge, skills, competencies always passes with certain mistakes and difficulties that cannot be (and should not be avoided), which reflects the heterochronous specificity of the person and with which one must consciously, tolerantly and balanced work. Heterochrony largely determines the incompleteness of a person and the openness of his being, which represents the ontological premise of his humanism, tolerance, creativity, transcendence and commitment to self-improvement, actualization and spirituality.

In the process of improving the health care competence of a Physical Education teacher in postgraduate education, we actively use the knowledge of heterochrony and actualize the need for the teacher to develop intellectual skills in the direction of heterochronically oriented interpretations of professionally significant phenomena and problems. This contributes to the humanization and axiologicalization of the educational process, the faster and effective assimilation of knowledge about the person and his health and motor sphere. Accordingly, professional and practical orientation and specification of knowledge about the person and his health and improvement on the basis of their health care competence. In educational theory and practice, knowledge of heterochrony is complementary, not competitive. They give the opportunity to open in front of the teacher in a representative, phenomenological, temporal and value-oriented way, to reveal the nature of man, which in comparison with other biological species is formed unevenly and long time. 
Yevtuch et al., 2020. Methodological Reflection on the Heterochronia in the Context of Development of a Health Preserving Competence of a Physical Education Teacher

Here are some important heterochrones, the knowledge about them we use to improve the health-care competency of a Physical Education teacher: due to the uneven growth in adolescence during puberty, the coordination opportunities that need to be taken into account for prevention are temporarily impaired; in children, the temporal and pelvic bones are not monolithic until 10-12 years of age, which requires special care when conducting Physical Education classes; The psychological problems of adolescents in the form of addictive, hypersexual, aggressive behavior or the development of accentuation of character are largely due to their uneven growth and formation, which requires the teacher's care, attention and purposeful psychological work. On the basis of these phenomena, we have developed the methodological recommendations on the technologies for working with them.

\section{Conclusions}

In order to improve the methodology and methods of health preserving competence of Physical Education teacher in conditions of post-graduate education on the basis of unveiling temporal ontology of a person and perception of his/her uneven and non-lineal ontogenesis, we have actualized the educationally significant and health oriented problematics - the methodological reflection of the heterochronia phenomenon. On the basis of methodologicalvalue reflection of the heterochronia phenomenon, which reflects the temporal phenomenology of a person, its non-lineal, procedural, poly-ontological, existential, harmonic, vital, auto-poetic, crisis and borderline nature, we have formed the practically oriented concepts of Homo Heterochronicum and heterochronic values.

The idea and the methodological and technical sense of development of the stated concepts is the professionalization, existentialization, anthropologization, humanization, axiologization, technologization and intellectualization of the process of improving the health preserving competence of a Physical Education teacher in conditions of post-graduate education as well as increasing the efficiency of educational practices and life and health preserving techniques. The concepts of Homo Heterochronicum and of heterochronic values are aimed at development in a Physical Education teacher of a health oriented, tolerant, merciful, kind, attentive, humane, responsible and delicate attitude to children that would be based on the awareness and value-based understanding of heterochronia as a manifestation of a temporal nature of a person and the staged and non-lineal peculiarity of a person's ontogenesis.

We fill the concept of heterochronia, which exists in physiology and biology, with pedagogical, life preserving, health preserving, technological and valuebased senses. In this pedagogical system heterochronia are defined as "cognitive- 
interpretative-value-temporal" concepts, which are formed by the following components: awareness about and understanding of the anthropological phenomenon, which is important for life and health preservation; the temporal component, which determines the significant time and its limits; value interpretations of the biological and psychological phenomenon; understandings and visions, which unveil the attitude and the importance of the stated phenomenon for life and health preservation.

Based on the transfer of medical knowledge with the aim of targeted, proofbased, objectivized, technologized, intellectualized, nature-corresponding and value oriented prevention of sudden cardiac death at Physical Education lessons and while doing sports, we determine three "cardiac heterochronia": "partial structural maturity of the cardiac nervous apparatus at the age of 7", "incomplete structural-functional maturity of the cardiac nervous apparatus at the age of 1113 " and "complete structural-functional maturity of the cardiac nervous apparatus at the age of 18-22".

We represent the awareness and value understanding of cardiac heterochronia as significant components of the methodological foundation of improving the health preserving competence as well as motor practices and techniques. The stated cardiac heterochronia provide value-based orientation and methodological determination of significant and systemic peculiarities of pedagogical health preserving and life preserving strategies, tactics, actions, cognitive schemes, visions, conditions and the specifics of the professional thinking of the Physical Education teacher (coach).

As the result of the conducted studies using the questionnaire entitled "Determining heterochronically oriented interpretation of health preservation", we have determined that the working Physical Education teachers show better awareness about and value oriented understandings of heterochronia in comparison with students majoring in Physical Education. We believe that the reflection of one's own experience, conducted by a Physical Education teacher, facilitates the educator's understanding of the temporal phenomenology of a person and his/her health, which also includes actualization of understandings concerning the significance and systemic nature of heterochronia.

\section{References}

Ananev, B.G. (1980). Izbranye psihologicheskie trudy. Moskva: Pedagogika.

Anohin, P.K. (1968). Biologiya i nejrofiziologiya ulovnogo refleksa. Moskva: Medicina.

Anohin, P.K. (1998). Kibernetika funkcionalnyh sistem. Moskva: Medicina.

Berger, S., Whitstone, B.N., Frisbee, S.J., Miner, J.T., Dhala, A., Pirrallo, R.G., Utech, L.M., \& Sachdeva, R.C. (2004). Cost-effectiveness of Project ADAM: a project to prevent sudden cardiac death in high school students. Pediatric Cardiology, 25(6), 660-67. 
Yevtuch et al., 2020. Methodological Reflection on the Heterochronia in the Context of

Development of a Health Preserving Competence of a Physical Education Teacher

Bertalanffy, L.Von. (2009). General System Theory. Foundations, Development, Applications. New York: George Braziller.

Binswanger, L. (1942). Grundformen und Erkenntnis Menschlichen Daseins. Zürich: Max Niehans Verlag.

Bollnow, O.F. (1971). Padagogik in anthropologischer Sicht. Tokyo: Tamagawa University Press.

DiFiori, J.P., Benjamin, H.J., Brenner, J., Gregory, A., Jayanthi, N., Landry, G.L., \& Luke, A. (2014). Overuse injuries and burnout in youth sports: A position statement from the american medical society for sports medicine. Clinical Journal Of Sport Medicine, 24(1), 3-20.

Fedorets, V.M. (2011). Analiz ta aktualizatsiia vzaiemodii vikovykh, nervovykh i lokomotornykh determinant kardiolohichnoho zdorovia $\mathrm{v}$ konteksti formuvannia zdoroviazberihaiuchoho pidkhodu. Fizychna kultura, sport ta zdorovia natsii, 12(3), 137-145.

Fedorets, V.M. (2017). Kontseptualizatsiia antropolohichnoi modeli zdoroviazberezhuvalnoi kompetentnosti vchytelia fizychnoi kultury. Visnyk pisliadyplomnoi osvity. Seriia «Pedahohichni nauky», 5(34), 137-178.

Fedorets, V.M., \& Klochko, O.V. (2019). Rozvytok zdoroviazberezhuvalnoi kompetentnosti vchytelia fizychnoi kultury na osnovi rozkryttia fenomenu zdorovia reprezentovanoho yak ekzystentsiia ta ontolohiia. Visnyk Chernihivskoho natsionalnoho universytetu imeni T.H. Shevchenka, 3(159), 223-235.

Fuko, M. (2008). Tehnologii sebya. Territoriya budushogo, 2(65), 96-122.

Gottschalk, A.W., \& Andrish, J.T. (2011). Epidemiology of sports injury in pediatric athletes. Sports Medicine And Arthroscopy Review, 19(1), 2-6.

Gusserl, E. (2004). Krizis evropejskih nauk i transcendentalnaya fenomenologiya. SanktPeterbrg: «Vladimir Dal».

Higgins, J., \& Andino, A. (2013). Soccer and Sudden Cardiac Death in Young Competitive Athletes: A Review. Journal of Sports Medicine, 1-7. DOI: 10.1155/2013/ 967183.

Jeger, V. (1997). Pajdejya. Vospitanie antichnogo greka. Moskva: Greko-latin. kabinet Yu. A. Shichalina, 2.

Knyazeva, H. (2018). Biosemiotics: The Origins of an Interdisciplinary Movement. Voprosy Filosofii, 11, 86-98. DOI: 10.31857/s004287440001897-1.

Krivo, Y.A. (2018). Socionika, fiziologiya, kognitivistika, model' funkcional'nyh sistem cheloveka dlya primeneniya v psihologii. Chelovek, iskusstvo, vselennaya Izdatel'stvo: Avtonomnaya nekommercheskaya organizaciya dopolnitel'nogo professional'nogo obrazovaniya "Centr razvitiya cheloveka", 1, 90-102.

Levin, K. (2000). Teoriya polya v socialnyh naukah. Sankt-Peterburg: «Sensor».

Mamakina, I.A. (2013). Formirovanie kognitivnogo komponenta zdorovesberegayushej kompetentnosti studentov fakulteta fizicheskoj kultury vuza sredstvami sovremennyh obrazovatelnyh tehnologij: avtoreferat disertacii kandidata pedagogicheskih nauk: 13.00.08. Ulyanovsk: Ulyanovskij gosudarstvennyj universitet.

Maron, B.J., \& Estes, N.A. (2010). Commotio cordis. The New England Journal Of Medicine, 362(10), 917-927.

Maturana, U., \& Varela, F. (2001). Drevo poznaniya: biologicheskie korni chelovecheskogo ponimaniya. Moskva: Progress-Tradiciya.

Millikan, R.G. (1984). Language, Thought, and Other Biological Categories: New Foundations for Realism. Cambridge, MA: MIT Press. 
Nonaka, I., \& Takeuchi, H. (2011). Kompaniya - sozdatel znaniya - Zarozhdenie i razvitie innovacij v yaponskih firmah. Moskva: Izdatelstvo: Olimp.

Nosov, N.A. (2000). Virtualnaya psihologiya. Moskva: Agraf.

Polani, M. (1985). Lichnostnoe znanie. Na puti k postkriticheskoj filosofii. Moskva: Progress.

Powell, J. (2001). Cerebral concussions: causes, effects, and risks in sports. Journal of Athletic Training, 36(3), 307-311.

Raven, Dzh., Yarygin, O.N., \& Korostelev, A.A. (2017). Kompetentologiya: ot prakseologii do sociokibernetiki. Azimut nauchnyh issledovanij: pedagogika i psihologiya, 6-1(18), 167-175.

Shvalev, V.N., Sosunov, A.A., \& Guski G. (1992). Morfologichekskie osnovy innervacii serdca. Moskva: Nauka.

Steinvil, A., Chundadze, T., Zeltser, D., Rogowski, O., Halkin, A., Galily, Y., Perluk, H., \& Viskin, S. (2011). Mandatory electrocardiographic screening of athletes to reduce their risk for sudden death proven fact or wishful thinking? Journal of the American College of Cardiology, 57(11), 1291-1296.

Ushinskij, K.D. (2005). Izbrannye trudy. V 4 kn. Kn. 3-4. Chelovek kak predmet vospitaniya. Opyt pedagogicheskoj antropologi. Moskva: Drofa.poznaniya: biologicheskie korni chelovecheskogo ponimaniya. Moskva: Progress-Tradiciya.

Van Camp, S.P., Bloor, C.M., Mueller, F.O., Cantu, R.C., \& Olson, H.G. (1995). Nontraumatic sports death in high school and college athletes. Medicine and Science in Sports and Exercise, 27(5), 641-647. 